\title{
Petrogenesis and element mobility of Neoarchean alkaline granitic gneissesin the southeastern margin of the North China Craton
}

\author{
SU HAIYAN, LIU YICAN AND YANG YANG
}

CAS Key Laboratory of Crust-Mantle Meterials and

Environments, School of Earth and Space Science,

University of Science and Technology of China, 230026, Hefei, China $\quad$ *correspondence:

shy17@mail.ustc.edu.cn)

The Wuhe complex (WC) in the Bengbu and neighboring areas is located at southeastern margin of the North China Craton (NCC) and belongs to the Precambrian metamorphic basement. The WC experienced the Palaeoproterozoic multistage granulite-facies metamorphism, accompanying close-to-coeval partial melting and heterogeneous carbonate metasomatism [1-3]. To illustrate the petrogenesis of the alkaline granitic gneisses and their element mobility during high-grade metamorphism and related partial melting, the rocks at Mashan from the WC have been investigated based on petrogeochemistry and zircon $\mathrm{U}-\mathrm{Pb}$ dating.

The alkaline granitic gneisses in this study are considered as meta-igneous rocks, on the basis of chemical and mineralogical criteria. The gneisses are characterized by $\mathrm{K}$ feldspar + quartzs + arfvedsonite + aegirine + biotite. The rocks are distinct with high $\mathrm{SiO}_{2}(69.85 \% \sim 74.51 \%)$ and high alkali $(9.67 \% \sim 12.17 \%)$. These geochemical features are similar to those from A-type granites, but have a pronounced positive anomaly of $\mathrm{Eu}, \mathrm{Sr}$ and $\mathrm{Ba}$. They are ascribed to multiple reworking related to felsic hydrothermal activity and carbonate metasomatism. The zircons from the rocks generally exhibit a typical core-mantle-rim texture in CL images. The igneous core domais are of oscillatory growth zoning and high $\mathrm{Th} / \mathrm{U}$ ratios $(0.4-1.3)$, and give $2.6-2.7 \mathrm{Ga}$. The positive $\varepsilon \mathrm{Hf}(\mathrm{t})$ values $(+2.5-+6.6)$ of magmatic zircons suggest that these gneisses were extracted from depleted mantle, suggestive of an important crustal growth event at 2.6-2.7 Ga, and were formed in an extensional tectonic setting. The metamorphic mantles overgrew during granulite-facies metamorphism, as evidenced by calcite + rutile $+\mathrm{K}$-feldspar + quartz inclusions and give $\sim 2.5 \mathrm{Ga}$. The rims are characterized by spherical to oval and give $\sim 1.8 \mathrm{Ga}$, indicating a late metamorphic overprinting.

This study was financially supported by the National Natural Science Foundation of China (41773020).

[1] Liu et al. (2009) JMG 27, 125-138. [2] Liu et al. (2017) Lithos 290-291, 189-209. [3] Wang et al. (2017) Precambrian Research 303, 268-290. 